and development. These principles respect the Convention on the Rights of the Child, which Argentina endorsed in October 1990 through Law no. 23849. Children and adolescents will take us by surprise with their questions, their ability to adapt to disease, their collaboration, and the great resilience they display in the relationship with their pediatricians.

We are now living a particularly difficult period in terms of physical, psychological, and social health. The pandemic has transformed our lives and mainly affected the way we interact with one another. The distance, hiding our faces behind a mask, and words which now travel through technological means, including screens, have deeply transformed our communication and the possibilities of getting closer. Telemedicine, whose use has increased in the current situation, although practical, will never replace a faceto-face meeting. It is worth noting that, in the "clinical space", communication can be verbal and non-verbal, but, in addition, the place where this visit occurs has a greater influence on message transmission or reception. It is not the same to talk in a hall or an office or behind open or closed doors, with a desk between us or around a round table, and the location also matters, whether it is a hospital, a clinic, a private office or the patient's house. In the hospital, communication will depend on the place of the meeting, whether a hospitalization ward or a private room. The clinical space also has its own protocols, which contribute to a better communication.

Choosing the place where we will meet with a child or adolescent and their family, preparing for such meeting, and adhering to professional rules are just some important steps that will benefit our patients. Let us not forget that we are not friends with our patients and that we will never take their parents' role, but we may make huge contributions to their well-being and improve their quality of life through empathy, understanding, and dialog. The "humanistic brain", which never stops improving thanks to face-toface meetings with patients and their families, thanks to reading, art, and life, will never be replaced by technology.

\section{Fernando Álvarez \\ Professor of Pediatrics CHU-Sainte Justine University of Montreal, Canada}

http: / / dx.doi.org/10.5546/ aap.2021.eng.220

To cite: Álvarez F. The past, present, and future role of pediatricians. Arch Argent Pediatr 2021;119(4):220-221.

\title{
Prohibition of the attachment bond in the Third Reich
}

Andrew Ivy, an expert in American medical ethics sent by the American Medical Association to testify in the Nuremberg Doctors' Trial, stated: "Had the profession taken a strong stand against the mass killing of sick Germans before the war, it is conceivable that the entire idea and technique of death factories for genocide would not have materialized. This sentinel genocide was largely conceived, led, and implemented by health professionals and scientists whose core duty should have been to protect the sick and the socially vulnerable". ${ }^{1}$ A paradigm of such sinister account is embodied by Austrian pediatrician and psychiatrist Hans Asperger (1906-1980), ${ }^{2}$ known for identifying Asperger syndrome, who actively assisted the Nazi regime under the child "euthanasia" program; he sent dozens of children to the child psychiatric clinic Am Spiegelgrund in Vienna, where they were killed due to their "uneducable" psychiatric problems. A total of 789 children were killed there between 1940 and 1945. ${ }^{3}$

In May 2017, almost 100 scholars, educators, and medical professionals from around the world met in Western Galilee, Israel, to discuss medicine during and after the Holocaust. The conference resulted in the drafting of what is now known as the Galilee Declaration, ${ }^{4}$ which affirms the Declaration of the Stockholm International Forum on the Holocaust and supplements it for health professions. It calls upon medical schools and other health care institutions to incorporate the 
study of medicine and the Holocaust. ${ }^{5}$

Let's start by analyzing the early bonding experiences between the baby and the parents in those times. The Nazi regime urged German mothers to ignore the emotional needs of their young children, which was considered best to raise soldiers and hardened fans. It may be summed up as the story of separation between mothers and babies. Johanna Haarer, a pulmonologist, was publicized as an expert in child-rearing during the Nazi Germany. In 1934, during the second year of the Nazi dictatorship, Johanna Haarer published her book The German Mother and Her First Child, which mainly focuses on medical issues and infant care. However, it also certainly discussed a "correct" upbringing, an education in authoritarianism. Roughness, rigor, discipline, and distance: what Haarer disseminated in her guidelines embodied the zeitgeist. She recommended isolating newborn infants for 24 hours after birth, and then making them sleep in a separate room. Her advice specifically denied a sensitive care in the first months of life. She suggested as little attachment as possible. Leaving the baby crying in their room was part of the routine. Haarer advised mothers against picking up their babies out of the crib, caressing them, holding them in their lap or feeding them during the night. Thus, they would not "raise a tiny tyrant at home". The Nazis wanted children who lacked emotions and empathy, weakly bonded to others. Haarer, an enthusiast of the regime, sold 1.2 million books, which gained an almost biblical recognition among German homes. During the Nazi regime, the book served as the basis for education in German day care centers and homes, as well as for "Reich mothers training courses". Recommendations were considered modern for the time, promoted as scientifically solid, and got the attention of all parents who identified with the Nazi regime. Haarer believed that it was necessary for every German citizen to become a "useful member of the Volksgemeinschaft (people's community)" and firmly opposed childrearing practices that encouraged children's individuality. Children had to learn to "become part of the community and subordinate their desires and efforts in the community's best interest".

Lastly, Haarer's work reflected and shaped child-rearing practices in line with the goals of the Hitler Youth. Parents were encouraged to have children who could become members of the community, did not show signs of self-pity or self-indulgence, and were brave, obedient, and disciplined. Counseling centers and training courses for mothers based on Haarer's ideas became a tool to instill the Nazi ideology.

Studies have shown that Haarer's advice was actually traumatizing. The final, undisclosed goal of such methods was to form submissive subjects who would blindly follow any authority figure, even if their orders were cruel and absurd.

Haarer had five children. Gertrud Haarer, her younger daughter, publicly challenged her mother's legacy and wrote a book about Johanna Haarer's life and ideas. In an interview with the Bavarian television, while discussing her own childhood, Gertrud Haarer said: "I was apparently so traumatized that I believed I would never have children of my own". ${ }^{6}$

The perspective during the Third Reich is also related to what psychologist Alice Miller ${ }^{7}$ (1923-2010) called poisonous pedagogy, a form of repressive education that prevailed in that time and aimed at subjugating children through different methods of physical punishment and mental manipulation.

Babies experience existential fear when they find themselves alone and hungry and do not receive any comfort from an attachment figure. Such trend contrary to the affectionate bond between an adult and a child was questioned in the $20^{\text {th }}$ century by authors like René Spitz (1887-1974) and John Bowlby (1907-1990) the latter was the author of the theory of attachment-, who exposed the negative impact that the separation of babies from their mothers during hospitalization (hospitalism) has on child survival. In our setting, in 1964, Florencio Escardó, M.D., was the first physician who took the initiative to allow mothers in the children's hospital ward led by him, not without resistance from the pediatric sector. ${ }^{8}$

The process leading towards respect of the attachment bond is still present: rooming-in instead of taking the baby to a nursery, skin-toskin care instead of separation of the mother-child dyad at the moment of birth. In the first minutes and hours of life, there is a sensitive period during which the mother-child dyad needs to establish an intimate contact ${ }^{9}$ so that their relationship subsequently develops in a favorable manner.

As physicians, we should always favor attachment, which is none other than the unique and specific relationship between two individuals 
that tends to persist over time: caresses, kisses, lullabies, and loving prolonged eye contact ${ }^{10}$ are what every human being needs to grow up free and healthy.

\section{Alejandro Jenik, M.D. ${ }^{a}$ and Estela Grad, M.D. ${ }^{b}$}

a. Associate of the Department of Neonatology, Division of Clinical Pediatrics. Hospital Italiano de Buenos Aires. Autonomous City of Buenos Aires. Task Force on Sleep Disorders and Sudden Infant Death, Sociedad Argentina de Pediatría.

b. Task force on Sleep Disorders and Sudden Infant Death. Committee on Social Pediatrics,

Sociedad Argentina de Pediatría.

E-mail address:

Alejandro Jenik, M.D.: alejandro.jenik@hospitalitaliano.org.ar

http:/ / dx.doi.org/10.5546/ aap.2021.eng.221

To cite: Jenik A, Grad E. Prohibition of the attachment bond in the Third Reich. Arch Argent Pediatr 2021;119(4):221-223.

\section{REFERENCES}

1. Ivy AC. Statement by Andrew C Ivy. In: Mistsherlich A Mielke F (eds). Doctors of infamy. The story of the Nazi medical crimes. New York: Henry Schuman; 1949.

2. Czech H. Hans Asperger, National Socialism, and "race hygiene". In: Nazi-era Vienna. Mol Autism. 2018; 9;29.

3. Weindling P. From scientific object to commemorated victim: the children of the Spiegelgrund. Hist Philos Life Sci. 2013; 35(3):415-30.

4. The Galilee Declaration. The Second International Conference on Medicine in the Holocaust and Beyond. 7-11 May 2017. Western Galilee, Israel. [Accessed on: March $\left.7^{\text {th }}, 2021\right]$. Available at: http://mededirect.org/ mimeh/galilee.cfm

5. Roelcke V, Hildebrandt S, Reis S. Announcing the Lancet Commission on Medicine and the Holocaust: Historical Evidence, Implications for Today, Teaching for Tomorrow. Lancet. 2021; 397(10277):862-4.

6. Haarer J, Haarer G. Die deutsche Mutter und ihr letztes Kind. Hannover: Offizin-Verlag; 2012.

7. Miller A. Por tu propio bien: raíces de la violencia en la educación del niño. Barcelona: Tusquets; 2006.

8. Diamant A. Florencio Escardo: La Psicología -y las Psicologías- y la lucha contra los múltiples prejuicios. Anu Investig (Fac Psicol Univ B Aires). 2007; 14:123-33.

9. Soto Conti C. Primera hora de vida: una ventana de oro. Rev Hosp Mat Inf Ramón Sardá. 2018; 3(3):167-78.

10. Klaus M, Kennell J. La relación madre-hijo: impacto de la separación o pérdida prematura en el desarrollo de la familia. Buenos Aires: Panamericana;1978. 